\title{
Colorimetric Analysis of Fusel Oil in Rums Using o-Nitrobenzaldehyde as Color Reagent ${ }^{1}$
}

\author{
Calixta S. de Torres and Juan Luis Aguiar ${ }^{2}$
}

\section{INTRODUCTION}

Gas chromatographic studies carried out recently in this laboratory by García Morin, Aguilera, and Torres $(1,2)^{3}$ have shown significant discrepancies in the fusel oil content of Puerto Rican rums as analyzed by colorimetric (b) and chromatographic (6) methods. The accuracy of the colorimetric method was questioned because the chromatographic method is more simple and specific. The colorimetric method is based on the method of Penniman (11), in which salicylaldehyde 4 is employed as the color reagent. Total fusel oil concentration is obtained by a comparison of the intensity of the color developed by the sample and the intensity of the color developed under similar conditions by a standard synthetic fusel oil solution.

Among the many factors affecting the colorimetric method, two, the color reagent and the composition of the standard solution, were suspected to be the principal sources of error. SA reacts with each of the alcohols that compose the fusel oil to produce colored products of different intensity; therefore, total fusel oil determined by this method depends on the qualitative composition of the fusel oil in the sample. The composition of the standard solution should compensate for the limitations in sensitivity of the method.

Chromatographic analysis of Puerto Rican rums showed their average fusel composition to differ materially from that of the standard solution used for the colorimetric determinations in this laboratory. The relative propyl alcohol content was particularly different, since it is found approximately 3 times higher in the rums than in the standard solution. This factor increases the error of the colorimetric method because this method is less sensitive to propyl alcohol than to the other alcohols.

Fusel oil content furnishes one of the principal criteria for judging type, quality, and purity of distilled liquors and rums. Its determination is therefore of importance in the chemical examination of such beverages. The

1 The results of this study were presented to the X Latin American Congress of Chemistry, San José, Costa Rica, February 2-9, 1969.

${ }^{2}$ Assistant Chemists, Rum Pilot Plant, Agricultural Experiment Station, Mayagüez Campus, University of Puerto Rico, Rio Piedras, P.R.

- Italic numbers in parentheses refer to the Literature Cited, p. 108-9.

- For convenience, the aromatic aldehydes discussed throughout this report are abbreviated as follows: Salicylaldehyde (SA); p-dimethylaminobenzaldehyde (PAB); o-nitrobenzaldehyde (ONB); 4-hidroxybenzaldehyde-3-sulfonic acid (HBS). 
exclusive recommendation for use of the chromatographic method in the analysis of fusel oil is not entirely satisfactory for the rum industry of Puerto Rico, because some quality control laboratories do not have a vapor chromatograph at their disposal. The development of a short, simple, and inexpensive method sensitive satisfactorily to propyl alcohol, as well as to the isobutyl and isoamyl alcohols, would be highly desirable as an alternate to the gas chromatographic method.

\section{LITERATURE REVIEW}

An early method for fusel oil determination described by Allen-Marquard (9) was based on the extraction of the higher alcohols; and the oxidation and titration of the resulting acids. The method is rather tedious and generally gives lower results, especially in the analysis of low molecular weight alcohols. Esterification of higher alcohols by a method using acetyl chloride has been reported by Schicktang et al. (12), but the acetylation technique requires skillful manipulation to produce results that are constant and accurate. In addition, poor results are obtained in the analysis of propyl alcohol. Colorimetric methods have relied on the Komarowsky reaction in which alcohols react with an aromatic aldehyde in the presence of sulfuric acid to form colored complexes. Most research dealing with colorimetric methodology has been aimed at discovery of color reagents that will yield products of high and similar color intensity when reacted with the alcohols which compose fusel oil. SA has been used for a long time in the analysis of isoamyl and isobutyl alcohols because of the high sensitivity of the method. However, its sensitivity is very low for analysis of propyl alcohol. The reaction of SA with ethyl alcohol, sample's solvent, has been a significant factor in the present trend for discontinuing its use as a color reagent.

PAB has been reported by Guymon and Nakagiri (4) as advantageous because of its insignificant reaction with ethyl alcohol but its relative sensitivity also is very low for the analysis of propyl alcohol. Matters and Schoenemann found HBS (7) better for the analysis of fusel because the color reaction takes place rapidly towards completion and consequently timing and temperature of the reaction cease to be critical factors. Propyl alcohol, however, cannot be analyzed with this reagent because it is lost as propylene during the preparation of the sample. Maurel et al. (8) developed a method using ONB. They claim this reagent is satisfactorily sensitive to propyl alcohol as well as to isobutyl and isoamyl alcohols. B. R. Glutz (B) studied Maurel's method and after some modifications reported good results for the analysis of low concentrations of fusel oil in brandies. This information seemed to indicate that ONB can be a useful reagent for the analysis of fusel oil in rums which, in general, present a high percent of propyl alcohol and a low total concentration of fusel oil. 


\section{EXPERIMENTAI PROCEDURE, METHODS, AND MATERIALS}

A three-stage experimental study was conducted for evaluation of ONB as a color reagent for analysis of fusel oil in Puerto Rican rums: 1, Evaluation and modification of Maurel's method and Glutz's modification for the application of ONB to the analysis of Puerto Rican rums; 2, comparison of the relative sensitivity of ONB for the analysis of propyl, isobutyl and isoamyl alcohols and the correspondent sensitivity presented by SA and $\mathrm{PAB}$; and 3, determination of the most adequate composition of the fusel oil reference solution.

Alcoholic solutions, synthetic fusel oil solutions, and commercial rums were analyzed by gas chromatography and the concentration so determined was used as the exact fusel oil content of the samples. The same samples then were analyzed by applying three colorimetric methods and each set of determinations was compared to the gas chromatographic data for the calculation of the percentage of accuracy. The principal criterion used for the selection among the colorimetric methods was percentage of accuracy, but other aspects such as speed and simplicity of the procedure also were considered.

Colorimetric determinations were conducted by using a Beckman Model $\mathrm{DU}^{5}$ spectrophotometer with a tungsten lamp. Pyrex absorption cells 12 x $12 \times 48 \mathrm{~mm}$. in size were used. For the chromatographic determinations an F \& $M$ model 810 vapor chromatograph with dual flame detectors was used. The analytical column was a 10-foot $x$ 18-inch stainless steel tube, loaded with 5 percent Carbowax 20M on Chromosorb W, 60/80 mesh, acid washed. The purity of the reagents used were of Analytical Reagent or American Chemical Society Standards; the isobutyl and isoamyl alcohols were Eastman Kodak Fusel Oil Standards.

\section{EXPERIMENTAL RESULTS AND DISCUSSION}

Alcoholic solutions of propyl, isobutyl and isoamyl alcohols were analyzed for fusel oil using ONB as the color reagent to determine their properties. The solutions exhibited an orange color, which was stable for more than 30 minutes after they had attained room temperature, thus permitting the analysis of several samples in the same run. Propyl alcohol, however, developed a less intensive color than isobutyl and isoamyl alcohols. There was no difference in the hue of the color regardless of the type of alcohol reacted, thus, qualitative determination of the sample could not be made. The solvent, ethyl alcohol, developed the same color although less intense

- Trade names are used in this publication solely for the purpose of providing specific information. Mention of a trade name does not constitute a guarantee, warranty, or endorsement by the Agricultural Experiment Station or as implying superiority to other similar products not mentioned. 
than the other alcohols, but in spite of its low intensity it is known to interfere in the analysis of the higher alcohols. Adequate control is necessary to be sure the proof of the standard solutions and that of the known sample to be analyzed are the same.

Absorption curves of the solutions of the reacted alcohols were determined (fig. 1). Isobutyl and isoamyl alcohols presented a mutual maximum absorption at $423 \mathrm{~m} \mu$, while propyl alcohol showed a maximum absorption at $406 \mathrm{~m} \mu$. Isobutyl and isoamyl alcohols coincided in their absorption

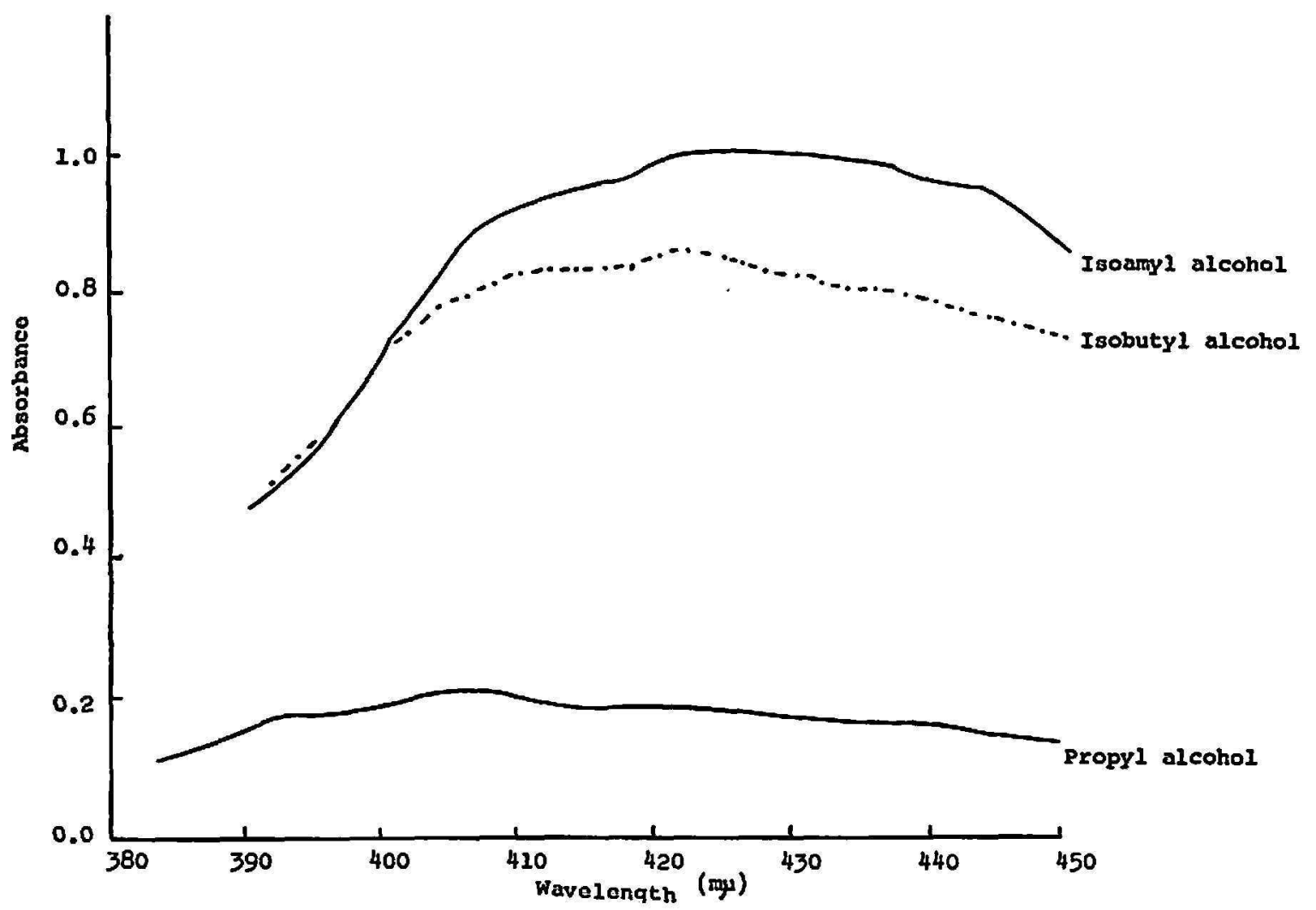

Fra. 1-Absorption curves of reacted alcohol solutions following Maurel's method.

curves at $400 \mathrm{~m} \mu$. Because of its proximity to the propyl alcohol maximum, $400 \mathrm{~m} \mu$ was selected as the wavelength of operation.

An inverse reaction of the proof of the solvent of the sample with the intensity of the color developed, was observed (fig. 2). The concentration of ONB was increased from 4 to 6 percent to determine if a lack of the color reagent was responsible. The analytical results, however, showed no significant increase in the intensity of the color (table 1). The concentration of the color reagent was established at 4 percent. The volume of sulfuric acid and the way in which it was added was altered from 10 to $15 \mathrm{ml}$, but no increase was observed in the intensity of the color developed (table 2). The time consumed per analysis was shortened by altering the cooling time required for each sample. This cooling time is now determined by the length 
- $20^{\circ}$ Proof solvent

$\triangle 80^{\circ}$ Proof solvent
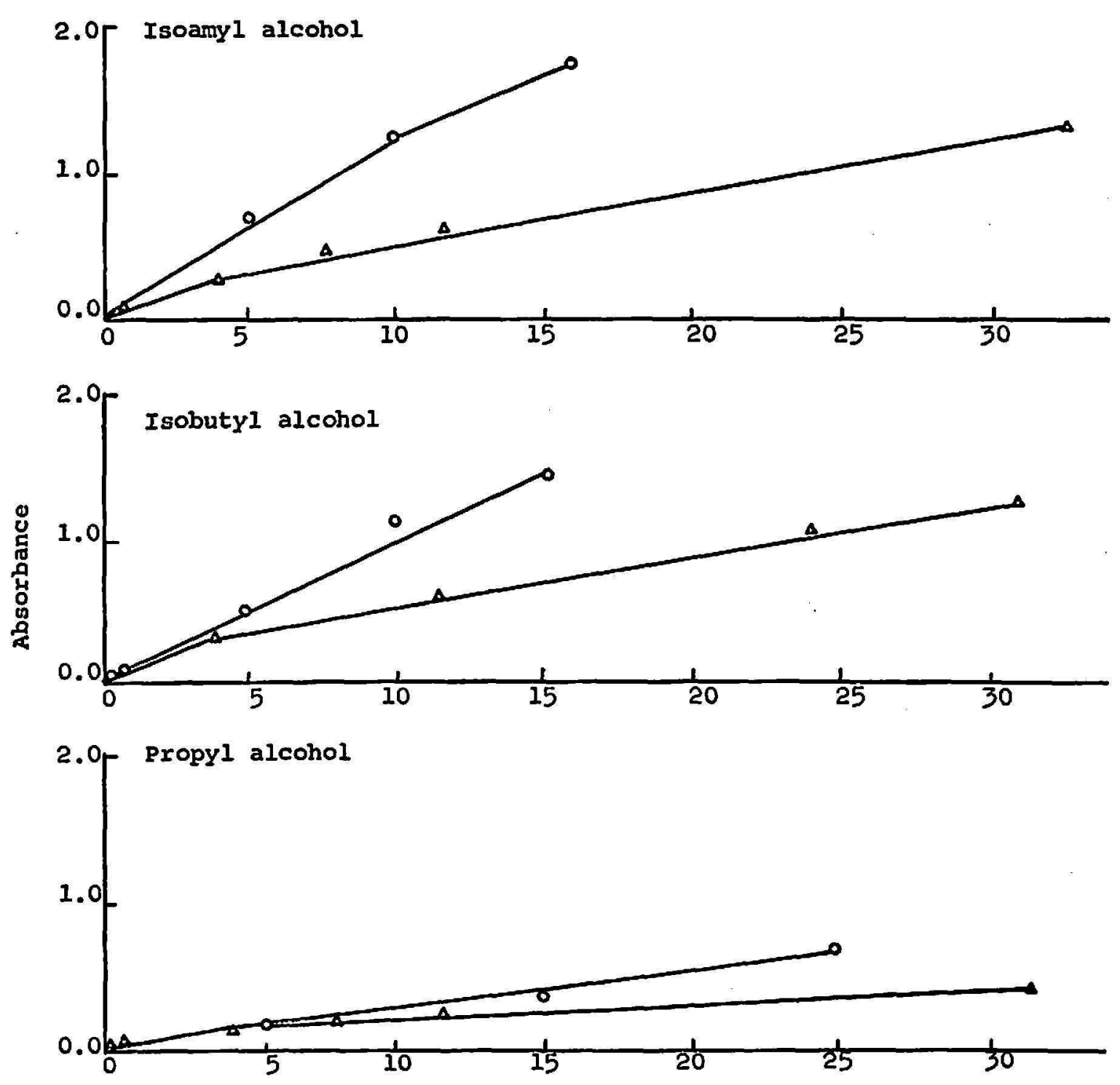

Mg./100 ml. higher alcohol

FIG. 2-Correspondence of the color developed with Beer's Law as affected by the proof of the sample's solvent using Maurel's method.

of time it takes to add the next required reagent to all other samples being analyzed. More samples can be analyzed in this way in the same period of time with no significant effect on the intensity of the color developed (table 3).

The stability of the color reagent dissolved in concentrated sulfuric acid and in absolute alcohol ${ }^{6}$ was found satisfactory for a period of 60 days (table 4).

Two other color reagents in addition to ONB were evaluated through two

- Recommended by Glutz as a solvent of the color reagent. 
TABLE 1. - Effect of the concentration of color reagent on the intensity of the color developed by the treated samples

\begin{tabular}{|c|c|c|c|}
\hline \multirow{2}{*}{ Sample } & \multirow{2}{*}{$\begin{array}{c}\text { Concentration (ms. } / 100 \mathrm{ml} \text {. o } \\
40^{\circ} \text { proof ethyl alcohol) }\end{array}$} & \multirow{2}{*}{\multicolumn{2}{|c|}{$\frac{\text { Percentage of ONB in concentrated } \mathrm{H}_{2} \mathrm{SO}_{4}}{\text { Absorbance of products }}$}} \\
\hline & & & \\
\hline $\begin{array}{c}\text { Propyl alcohol } \\
\text { Do. } \\
\text { Isobutyl alcohol } \\
\text { Do. } \\
\text { Isoamyl alcohol } \\
\text { Do. }\end{array}$ & $\begin{array}{r}4.0 \\
10.2 \\
5.3 \\
10.2 \\
5.1 \\
10.6\end{array}$ & $\begin{array}{c}\text { 4-percent } \\
0.15 \\
.33 \\
.48 \\
1.10 \\
.69 \\
1.28\end{array}$ & $\begin{array}{c}\text { 6-percont } \\
0.11 \\
.33 \\
.52 \\
.94 \\
.64 \\
1.16\end{array}$ \\
\hline
\end{tabular}

TABLE 2.-Effect of the volume of concentrated $\mathrm{H}_{2} \mathrm{SO}$, on the intensity of the color developed by the treated sample

\begin{tabular}{|c|c|c|c|c|}
\hline \multirow[b]{2}{*}{ Sample } & \multirow{2}{*}{$\begin{array}{c}\text { Concentration (mg } / 100 \\
\text { ml. of } 40^{\circ} \text { proof ethyl } \\
\text { alcohol) }\end{array}$} & \multicolumn{3}{|c|}{$\begin{array}{l}\text { Volume of concentrated } \mathrm{H}_{2} \mathrm{SO}_{4} \text { and } \\
\text { absorbance of products }\end{array}$} \\
\hline & & $10 \mathrm{ml}$. & $15 \mathrm{ml}$. & $\begin{array}{c}10 \mathrm{ml} \text {. before } \\
\text { heating time, } \\
\text { plus } 5 \text { mil. after } \\
\text { beating time }\end{array}$ \\
\hline $\begin{array}{c}\text { Propyl alcohol } \\
\text { Do. } \\
\text { Isobutyl alcohol } \\
\text { Do. } \\
\text { Isoamyl alcohol } \\
\text { Do. }\end{array}$ & $\begin{array}{r}4.0 \\
10.2 \\
5.3 \\
10.2 \\
5.1 \\
10.6\end{array}$ & $\begin{array}{r}0.15 \\
.33 \\
.48 \\
1.10 \\
.69 \\
1.28\end{array}$ & $\begin{array}{r}0.05 \\
.37 \\
.41 \\
.73 \\
.37 \\
.80\end{array}$ & $\begin{array}{r}0.05 \\
.51 \\
.51 \\
.82 \\
.51 \\
.85\end{array}$ \\
\hline
\end{tabular}

TaBLD 3.-Cooling time v8. intensity of the color developed by treated sample

\begin{tabular}{c|c|c|c|c}
\hline Sample & First cooling time & Second cooling time & Third cooling time & $\begin{array}{c}\text { Absorbance of } \\
\text { products }\end{array}$ \\
\cline { 2 - 4 } 1 & Minutes & Minutes & Minutes & Percent \\
2-a & 9.0 & 14 & 13 & 0.00 \\
$2-b$ & 9.5 & 15 & 10 & .80 \\
$2-\mathrm{c}$ & 10.5 & 15 & 8 & .83 \\
$2-\mathrm{d}$ & 11.5 & 15 & 6 & .82 \\
$2-\mathrm{e}$ & 12 & 16 & 3 & .79 \\
\hline
\end{tabular}

standard procedures, the Rum Pilot Plant's colorimetric method ( 5 ) and the Association of Official Agricultural Chemists PAB colorimetric method $(10)$, to determine their relative efficiencies in accurately analyzing the total fusel oil content of a sample, independent of its qualitative composition (table 5). 
$\mathrm{SA}, \mathrm{ONB}$, and $\mathrm{PAB}$ were studied and found to reflect an average error of 29,36 , and 40 percent, and 73,79 , and 76 percent average reproducibility, respectively.? $\mathrm{ONB}$ and $\mathrm{PAB}$ revealed a dependency on the relative propyl

TABLE 4.-Stability of a 4-percent ONB solution vs. age of the solution in different solvents

\begin{tabular}{c|c|c}
\hline \multirow{2}{*}{$\begin{array}{c}\text { Age } \\
\text { (days) }\end{array}$} & \multicolumn{2}{|c}{ Absorbance } \\
\cline { 2 - 3 } & Solvent: concentrated H2SO, & Solvent: 100-percent etbyl alcohol \\
\hline 0 & 2.229 & 2.149 \\
30 & 2.161 & 2.187 \\
60 & 2.260 & 2.187 \\
\hline
\end{tabular}

TABLE 5.-Composition of synthetic fusel oil standard solutions vs. registered absorbance (A) and resulting total fusel oil concentration (F.O.) in $\mathrm{mg} .1100 \mathrm{ml}$.

\begin{tabular}{|c|c|c|c|c|c|c|c|c|c|c|c|}
\hline \multirow{3}{*}{$\begin{array}{l}\text { Solution } \\
\text { No. }\end{array}$} & \multirow{3}{*}{$\begin{array}{c}\mathrm{Mg}_{\mathrm{f}} / 100 \\
\text { mi. of } \\
\text { weighed } \\
\text { total } \\
\text { fusel oil }\end{array}$} & \multicolumn{3}{|c|}{$\begin{array}{l}\text { Mg. } / 100 \text { ml. of each } \\
\text { alcohol in the solution }\end{array}$} & \multirow{3}{*}{$\begin{array}{c}\text { Ratio a } \\
\text { = Propyl } \\
\text { (Isobutyl } \\
+ \\
\text { Isoamyl) }\end{array}$} & \multicolumn{6}{|c|}{ Methods } \\
\hline & & & & & & \multicolumn{2}{|c|}{ Rum Pilot Plant } & \multicolumn{2}{|c|}{ Maurel } & \multicolumn{2}{|c|}{ A.O.A.C. ${ }^{2}$} \\
\hline & & 28080 & butyl & & & A & $\begin{array}{l}\text { Total } \\
\text { F.O. }\end{array}$ & $\mathbf{A}$ & $\begin{array}{l}\text { Total } \\
\text { F.O. }\end{array}$ & A & $\begin{array}{l}\text { Total } \\
\text { F.0. }\end{array}$ \\
\hline 1 & 9.7 & 1.9 & 1.9 & 5.9 & 0.243 & .143 & 12.0 & 0.802 & 8.2 & 1.328 & $\mathbf{8 . 0}$ \\
\hline 2 & 9.7 & 5.8 & 1.9 & 2.0 & 1.487 & .108 & 10.5 & .465 & 5.0 & .896 & $\mathbf{5 . 0}$ \\
\hline 3 & 9.8 & 0 & 1.9 & 7.9 & 0 & .161 & 15.5 & .965 & 9.8 & 1.480 & 9.2 \\
\hline 4 & 19.3 & 13.5 & 1.9 & 3.9 & 2.327 & .145 & 14.2 & .790 & 8.0 & .684 & 5.3 \\
\hline 5 & 19.6 & 1.9 & 3.9 & 13.8 & .107 & .345 & 32.8 & 1.660 & 22.0 & 1.328 & 15.0 \\
\hline 6 & 19.5 & 7.7 & 3.9 & 7.9 & .652 & .276 & 26.8 & 1.321 & 16.0 & 1.040 & 12.0 \\
\hline 7 & 29.3 & 9.7 & 2.9 & 16.7 & .495 & .293 & 28.0 & 1.585 & 21.0 & 1.850 & 18.0 \\
\hline 8 & 29.1 & 23.2 & 3.9 & 2.0 & 3.932 & .225 & 21.5 & .970 & 10.0 & .950 & 8.2 \\
\hline 9 & 29.1 & 18.4 & 1.9 & 8.8 & 1.720 & .202 & 19.3 & 1.301 & 15.8 & 1.200 & 11.0 \\
\hline 10 & 39.2 & 5.8 & 3.9 & 29.5 & .174 & .474 & 42.8 & - & - & - & 30.0 \\
\hline 11 & 39.0 & 14.5 & 6.8 & 17.7 & .569 & .515 & 48.5 & 1.959 & 27.5 & - & 25.0 \\
\hline 12 & 38.8 & 21.2 & 1.9 & 15.7 & 1.204 & .269 & 25.5 & 1.678 & 22.5 & - & 22.0 \\
\hline
\end{tabular}

1 Association of Official Agricultural Chemists.

alcohol content, as well as on the content of isobutyl and isoamyl alcohols (figs. 3 and 4). This is a disadvantage when SA is used.

The correspondence of the color developed with Beer's law was not uniform through the studied $0-40 \mathrm{mg} . / 100 \mathrm{ml}$. total fusel oil concentration range. Two straight lines, with two different tangents fit the experimental

7 The average error and reproducibility here indicated apply only to the specific method here described, and do not represent the accuracy and precision claimed by the official method. 


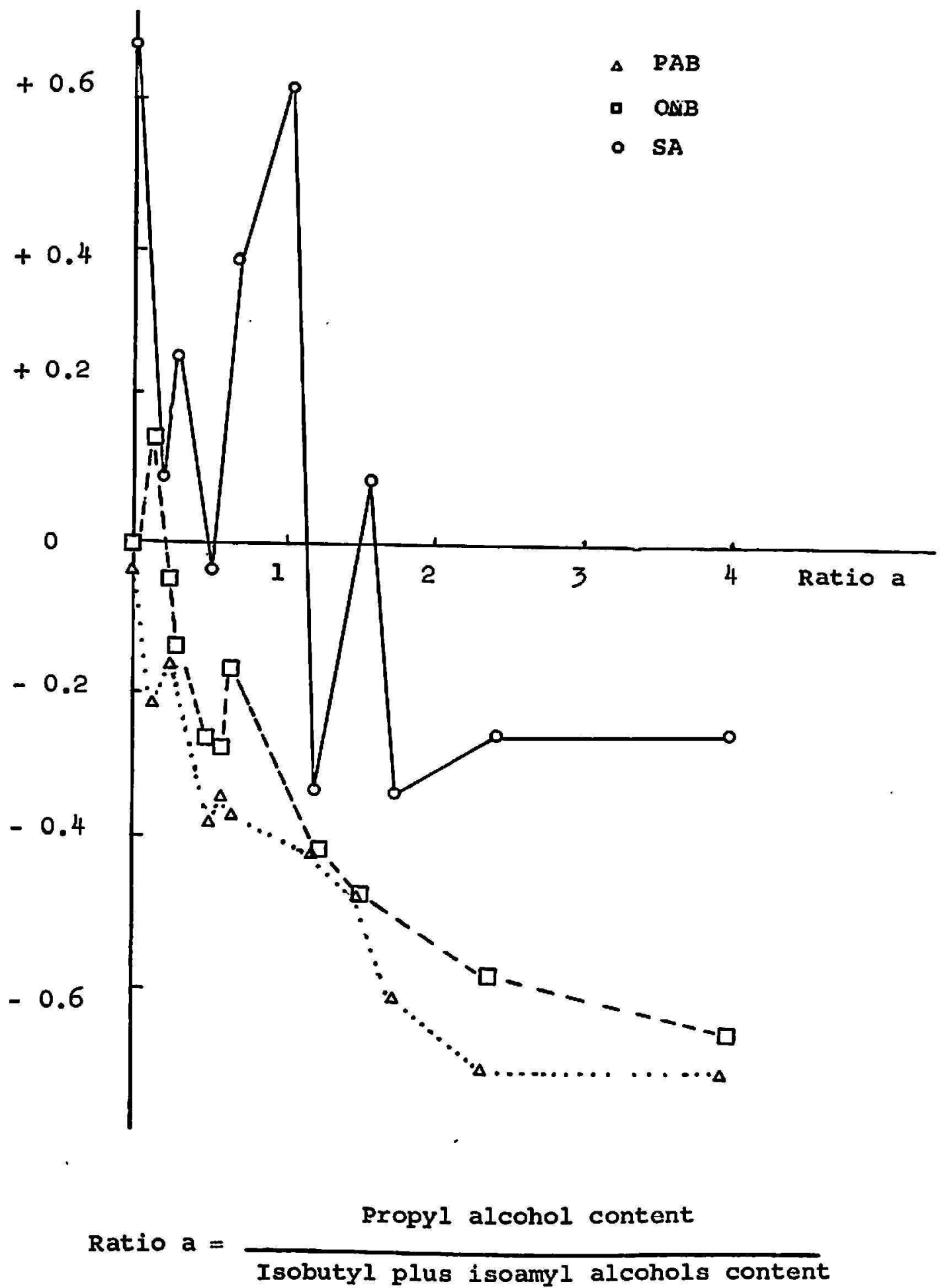

Frg. 3-Dependence of the error of fusel oil determinations on the relative propyl alcohol content of the sample.

data from the analysis of synthetic standard solutions better than a single straight line (fig. 2). Solvent proof proved to be a factor in the magnitude of the normal one straight line correspondence with Beer's law: As the solvent proof decreased, Beer's law was obeyed in a wider range of concen- 
tration. It was found that use of a regression line (the best straight line that fits the experimental data) gives analytical results significantly similar to those obtained from the use of the two experimental straight lines or from the use of one of the experimental straight lines combined with proper

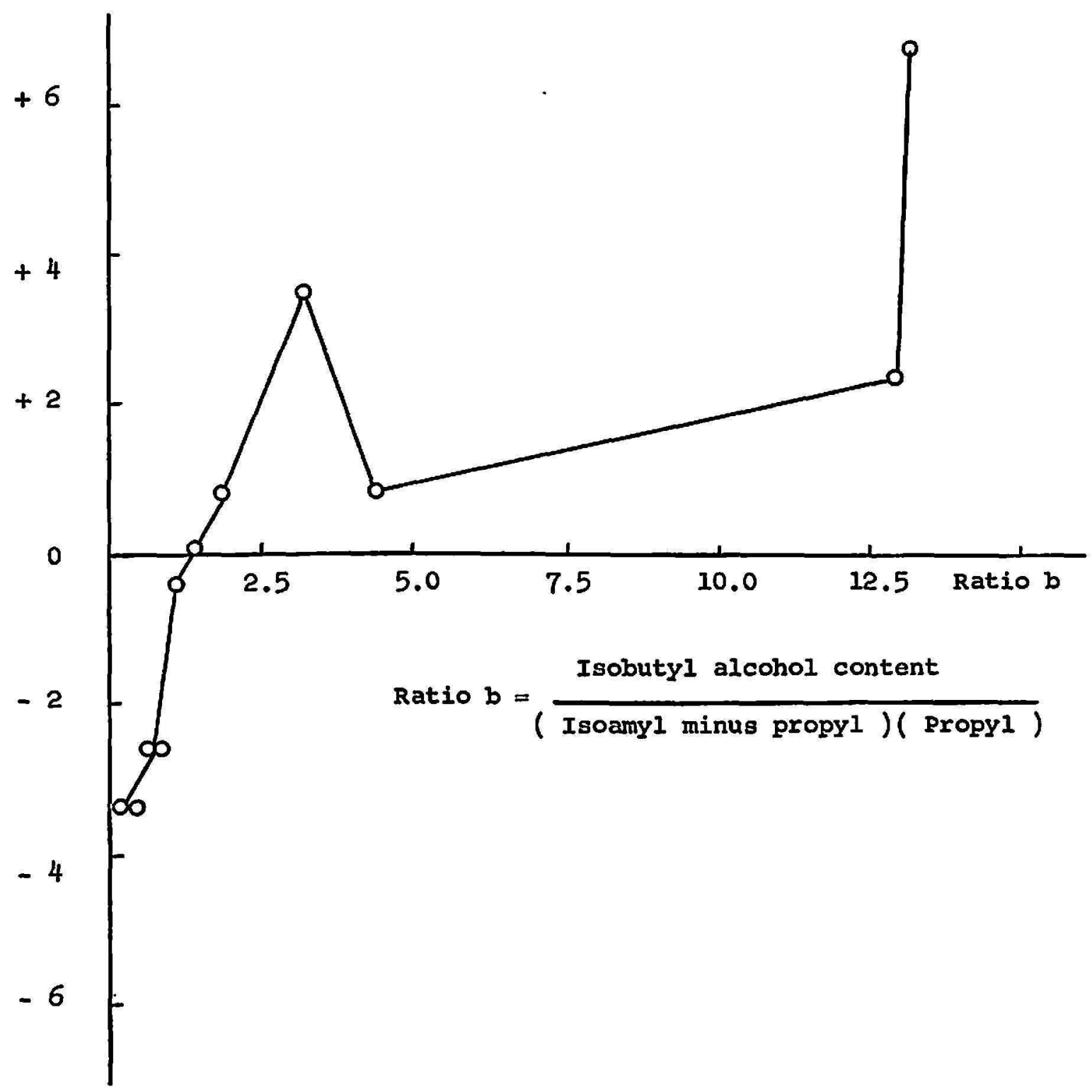

Fro. 4-Dependence of the error of salicylaldehyde determinations on the relative propyl and isobutyl alcohols content of the sample.

dilution of high fusel oil content samples (table 6). The regression line obtained from the analysis of standard synthetic fusel oil solutions was adopted as the calibration curve of the method.

The composition of the standard synthetic fusel oil solution was found to be of less importance in the explanation of the discrepancies between gas chromatographic and colorimetric determinations than the propyl alcohol content of the samples. Acceptable results were obtained (table 7) through 
TABLE 6.-Determination of fusel oil in rum samples by Maurel's method using three different calibration curves

\begin{tabular}{l|c|c|c}
\hline & \multicolumn{3}{|c}{ Mg./100 ml. total fusel oil } \\
\cline { 2 - 4 } Rum sample & $\begin{array}{c}\text { Two diferent } \\
\text { consecutive experi- } \\
\text { mental lines as } \\
\text { calibration curve }\end{array}$ & $\begin{array}{c}\text { One experimental line } \\
\text { combined pith proper } \\
\text { sample dilution as } \\
\text { calibration curve }\end{array}$ & Regression line \\
\cline { 2 - 4 } Gold label & & & \\
R-507 & 48 & 34 & 38 \\
R-508 & 64 & 50 & 47 \\
R-513 & 56 & 43 & 42 \\
R-517 & 13 & 13 & 14 \\
R-521 & 11 & 11 & 12 \\
R-526 & 5.2 & 5.2 & 5.2 \\
& & & \\
White label & 39 & 39 & 33 \\
R-506 & 29 & 18 & 27 \\
R-512 & 20 & 20 & 21 \\
R-515 & 40 & 40 & 34 \\
R-519 & 13 & 13 & 14 \\
R-525 & & & \\
\hline
\end{tabular}

TABLB 7.-Determination of fusel oil in rum samples using three different synthetic standard solutions by Maurel's method, in $\mathrm{mg} . / 100 \mathrm{ml}$.

\begin{tabular}{|c|c|c|c|}
\hline \multirow[b]{2}{*}{ Rum sample } & \multicolumn{3}{|c|}{ Pexcept of alcohols in standard solutions } \\
\hline & $\begin{array}{cc}1 & \\
\text { Propyl } & 55 \\
\text { Isobutyl } & 7 \\
\text { Isoamyl } & 38\end{array}$ & $\begin{array}{cc}2 & \\
\text { Propyl } & 45 \\
\text { Isobutyl } & 15 \\
\text { Isoamyl } & 40\end{array}$ & \begin{tabular}{cr}
\multicolumn{2}{c}{3} \\
Propyl & 16 \\
Isobutyl & 12 \\
Isoamyl & 60 \\
Isutyl & 7 \\
Ambyl & 5
\end{tabular} \\
\hline $\begin{array}{c}\text { Gold label } \\
\text { R-507 } \\
\text { R-508 } \\
\text { R-513 } \\
\text { R-517 } \\
\text { R-521 } \\
\text { R-526 }\end{array}$ & $\begin{array}{c}38 \\
47 \\
42 \\
14 \\
12 \\
5.2\end{array}$ & $\begin{array}{c}49 \\
61 \\
55 \\
16 \\
13 \\
5.2\end{array}$ & $\begin{array}{c}40 \\
50 \\
45 \\
14 \\
12 \\
4.0\end{array}$ \\
\hline $\begin{array}{c}\text { White label } \\
\text { R-506 } \\
\text { R-512 } \\
\text { R-515 } \\
\text { R-519 } \\
\text { R-525 }\end{array}$ & $\begin{array}{l}33 \\
27 \\
21 \\
34 \\
14\end{array}$ & $\begin{array}{l}42 \\
34 \\
26 \\
44 \\
16\end{array}$ & $\begin{array}{l}35 \\
28 \\
22 \\
36 \\
14\end{array}$ \\
\hline
\end{tabular}


the use of a calibration curve prepared from the analysis of standard solutions with different proportions of the higher alcohols. However, the following standard fusel oil solution is recommended because it was designed following the present average alcohol content of Puerto Rican rums: 46 percent propyl alcohol, 14 percent isobutyl alcohol and 40 percent isoamyl alcohol dissolved in $40^{\circ}$ proof ethyl alcohol. ${ }^{8}$

Analytical results were found reproducible using a relative permanent calibration curve instead of daily calibration (table 8), and also using calibration curves prepared on different dates (table 9).

TABLE 8.-Determination of fusel oil in rum samples using a relatively permanent calibration curve and a calibration curve prepared daily 1

\begin{tabular}{c|c|c}
\hline Rum sample & $\begin{array}{c}\text { Relative permanent calibration } \\
\text { curve }\end{array}$ & $\begin{array}{c}\text { Daily preparation of a } \\
\text { calibration curve }\end{array}$ \\
\hline R-508 & 53 & 45 \\
R-512 & 33 & 28 \\
R-521 & 15 & 12 \\
R-525 & 16 & 13 \\
\hline
\end{tabular}

1 Results expressed in $\mathrm{mg}$. of fusel oil per $100 \mathrm{ml}$.

TABLE 9.-Effect of age of the calibration curve on the determination of fusel oil in rum samples

\begin{tabular}{c|c|c}
\hline Rum sample & Curve (1) & Curve (2) 2 months old \\
\hline R-508 & 47 & 45 \\
$R-512$ & 27 & 28 \\
$R-521$ & 12 & 12 \\
$R-525$ & 14 & 13 \\
\hline
\end{tabular}

Glutz's modification of Maurel's method was evaluated in the Rum Pilot Plant laboratory. Glutz introduced, among other less important factors, air as a reference solution for the spectrophotometric measure of the color developed, a variation in the concentration of the ONB, and the heating time. Our evaluation of these modifications demonstrated no advantage in accuracy (table 10) and no convenience in the recommended procedure.

Maurel's method, as modified in the Rum Pilot Plant laboratory, was compared with two other colorimetric methods and with the Rum Pilot Plant's chromatographic method. Similar accuracy was found among the

8 Puerto Rican rums are bottled at $80^{\circ}$ proof, but at the time of analysis they are reduced to $40^{\circ}$ proof, because of a twofold dilution introduced by a required sample distillation. 
colorimetric methods when compared to the chromatographic data (table 11), but the ONB method proved to be less complex and less time consuming. There was no acceptable correlation between the results by the ONB and chromatographic determinations due principally to the low sensibility of

TABLE 10.-Comparative fusel oil determinations using Glutz modification of Maurel's method and three other methods 1

\begin{tabular}{c|c|c|c|c}
\hline & \multicolumn{4}{|c}{ Methods } \\
\cline { 2 - 5 } Rum sample & Maurel & Glutz & Rum Pilot Plant & Gas chromatograph \\
\hline R-508 & 47 & 38 & 45 & 38 \\
R-512 & 27 & 18 & 26 & 47 \\
R-521 & 12 & 10 & 13 & 23 \\
R-525 & 14 & 14 & 15 & 24 \\
\hline
\end{tabular}

1 Results expressed in mg. of fusel oil per $100 \mathrm{ml}$.

TABLE 11.-Analysis of fusel oil in Puerto Rican rums using 4 different methods

\begin{tabular}{l|c|c|c|c}
\hline & \multicolumn{3}{|c}{ Mg./100 ml, total fusel oil } \\
\cline { 2 - 4 } & \multicolumn{3}{|c|}{ Colorimetric methods } & Gas chromatograph \\
\cline { 2 - 4 } & Maurel & Rum Pilot Plant & A.0.A.C. & \\
\hline Gold label & & & & \\
R-507 & 38 & 35 & 34 & 39 \\
R-508 & 47 & 45 & 45 & 38 \\
R-513 & 42 & 48 & 44 & 34 \\
R-517 & 14 & 12 & 17 & 12 \\
R-521 & 12 & 13 & 17 & 23 \\
R-526 & 5.2 & 2.4 & 5.0 & 2.1 \\
\hline White label & & & & \\
R-506 & 33 & 38 & 36 & 33 \\
R-512 & 27 & 26 & 31 & 47 \\
R-515 & 21 & 25 & 19 & 28 \\
R-519 & 34 & 34 & 26 & 35 \\
R-525 & 14 & 15 & 20 & 24 \\
\hline
\end{tabular}

the colorimetric method for the analysis of propyl alcohol. The method developed is thus recommended as an alternative to the other colorimetric methods for the determination of fusel oil in rums.

\section{SUMMARY}

A new color reagent, o-nitrobenzaldehyde (ONB) was evaluated as a means of analysing the relatively high percentage of propyl alcohol in the 
fusel oil of Puerto Rican rums. The study comprised the establishment of the properties of the color developed by the products of the reaction, the effect of the proof of the solvent of the samples in the analysis and the relative sensitivity of the method for each of the alcohols that compose the fusel oil. The evaluation included the efficiency of other color reagents, salicylaldehyde (SA) and p-dimethylaminobenzaldehyde (PAB), in the analysis of total fusel oil content of a sample independent of its qualitative composition.

The most adequate composition of the standard solution used as reference for the analysis is recommended. From the results obtained, a method is recommended, which compares satisfactorily with two other official colorimetric methods, because it is more simple and rapid. There was no acceptable correlation between the results of the ONB method and the gas chromatographic method, due principally to the low sensitivity of the colorimetric method for analysis of propyl alcohol. The method is, however, useful as an alternate for the colorimetric analysis of fusel oil in rums.

\section{RESUMEN}

A fin de desarrollar un método para el análisis colorimétrico del aceite de fúsel, adecuado al contenido relativamente alto del alcohol propílico en los rones de Puerto Rico, se estudiaron las propiedades del reactivo o-nitrobenzaldehído (ONB) para el disarrollo del color.

Para este estudio se determinó el efecto del grado prueba de las muestras y del contenido de los alcoholes propílico, isobutilico e isoamílico en las muestras, tanto como su concentración total de aceite de fúsel, en la tangente de la curva de concentración vs. absorbancia de los productos de la reacción. Se estudió y evaluó la efectividad del ONB para analizar el contenido de aceite de fúsel total de una muestra independientemente de la composición cualitativa de la misma, y se comparó el resultado con la efectividad correspondiente de otros dos reactivos usados para el desarrollo del color: p-dimetilaminobenzaldehído (PAB) y saliciladehído (SA). Se recomienda la composición de la solución patrón de referencia más adecuada para el análisis del fúsel en los rones de Puerto Rico.

A base de los resultados obtenidos se recomienda un método analítico tan satisfactorio como otros dos métodos parecidos en los que se utilizan PAB y SA pero, aventajándolos en sencillez y rapidez. No se consiguió una reproducción satisfactoria de los resultados del análisis cromatógráfico, debido mayormente a la poca sensitividad del método colorimétrico para el análisis del alcohol propílico.

\section{LITERATURE CITED}

1. García Morín, M., Aguilera, C., and Torres, C., Analysis of Puerto Rican Rums by Gas Chromatography, accepted for publication in the Proceedings of the 
XII Congress, I.S.S.C.T., Elsevier Publishing Co., Amsterdam, Holland, February, 1965.

2. - Análisis de Rones de Puerto Rico por Cromatografía de Vapor, aceptada para publicación en Memorias, IX Congreso Latinoamericano de Química, San Juan, P.R., Agosto, 1965.

3. Glutz, B. R., Uber die analyse von spiriten, Mitt. Gib. Libensmittellunters Hyg. 68 (2): 114-29, 1967.

4. Guymon, F., and Nakagiri, J., Methods for the determination of fusel oil, Proc. Am. Soc. Enologists 8: 117-17, 1952.

5. Manual de Métodos Analíticos de la Planta Piloto de Ron, Agr. Expt. Sta., Mayaqüez Campus, Univ. P.R., Río Piedras, P.R., Determinación del Aceite de Fúsel en los Espiritus Destilados Usando un Espectrofotómetro, pág. 7, Enero, 1969.

6. Ibid, Determinación de los Congenéricos en los Rones y Otras Bebidas Alcohólicas por Cromatografía de Vapor, pág. 43, Enero, 1969.

7. Matters, A., and Schoeneman, R., 4-Hidroxybenzaldehyde-3-sulfonic acid as a reagent in the colorimetric fusel oil determination, J. A.O.A.C. 39: 834-44, 1965.

8. Maurel, A., Sansoulet, O., and Giffard, Y., Etude de la determination des alcools superieurs dans les eaux-de-vie, Ann. Fals. Expert. Chim. 58: (667): 219-27, 1965.

9. Official and Tentative Methods of Analysis, Association of Official Agricultural Chemists, A.O.A.C., 4th ed., Washington, D.C., p. 172, 1935.

10. Official Methods of Analysis, Association of Official Agricultural Chemists, A.O.A.C., 10th ed., Washington, D.C., p. 136, 1965.

11. Penniman, W., Smith, D., and Lawshe, E., Determination of higher alcohols in distilled spirits, Ind. and Eng. Chem. Anal. Ed. 9: 91-5, 1937.

12. Schicktang, S., Etienne, A., and Young, J., Determining the amyl alcohol content of distilled spirits, Ind. and Eng. Chem. Anal. Ed. 11: 390-402, 1939. 